\title{
Molecular Characterization of Imazaquin Tolerant and Sensitive Cowpea Genotypes
}

\author{
Abdulrahman Lado ${ }^{1}$, Muhammad Auwal Hussaini ${ }^{1}$, Alpha Yaya Kamara ${ }^{2}$ \\ ${ }^{1}$ Department of Agronomy, Bayero University, Kano, Nigeria \\ ${ }^{2}$ International Institute of Tropical Agriculture, Kano Station, Nigeria
}

Email address:

abdulladodoka@yahoo.com (A. Lado)

\section{To cite this article:}

Abdulrahman Lado, Muhammad Auwal Hussaini, Alpha Yaya Kamara. Molecular Characterization of Imazaquin Tolerant and Sensitive Cowpea Genotypes. International Journal of Genetics and Genomics. Vol. 4, No. 2, 2016, pp. 5-10. doi: 10.11648/j.ijgg.20160402.11

Received: March 20, 2016; Accepted: April 1, 2016; Published: April 16, 2016

\begin{abstract}
In this paper, to investigate the tolerance of some cowpea genotypes to imazaquin, seeds of 30 cowpea genotypes were treated with imazaquin at $0.06 \mathrm{~kg}$ active ingredient $\mathrm{ha}^{-1}$ and control were treated with distilled water. Treated seeds were planted in plastic pots and raised for 3 weeks in a green house. Samples leaves were detached for DNA isolation at 2 weeks after sowing. Phenotypic result revealed that Hen-me and Hodi were the most tolerant (with $12.5 \%$ mortality rate) to imazaquin while Maptwapa and many others (with 100\% mortality rate) were highly sensitive to imazaquin. However, there were no sequences differences between tolerant and sensitive genotypes in amplified region of the annotated portion of AHAS (acetohydroxy-acid synthase) from cowpea. It can be concluded that the major significant difference between imazaquin tolerance and sensitive cowpea is as a result of rapid metabolic detoxification of herbicides in tolerant cowpea. It is therefore imperative that enzymology involve in the differential metabolism of this herbicide in this crop needs urgent and necessary attention.
\end{abstract}

Keywords: AHAS Enzyme, Imazaquin, Herbicide Tolerance and Cowpea Genotypes

\section{Introduction}

Cowpea (Vigna unguiculata L. Walp) is one of the most important grain legume crop grown in sub-Saharan Africa. Apart from its nutritional importance, it is also an important component in modern and traditional cropping systems [1]. It is widely use in crop rotation and intercropping with many cereals because of its nitrogen fixing ability. Almost all parts of the crop are useful. The seeds are used for human consumption while the haulm (stems and leaves) as animals feed [2]. The young pods and leaves are used as vegetables. Its ability to tolerate drought and do well under poor soil conditions, makes it a desirable crop in savanna ecology. Elsewhere cowpea is grown as cash a crop.

Imazaquin belongs to imidazolinones group of herbicides for broadleaf and grass weed control in soybean [3]. It can be applied as pre-plant incorporated, pre-emergence or postemergence [4]. It is readily absorbed by root, foliage and rapidly translocated throughout the plant via xylem and phloem with accumulation in the meristmatic tissue.
Imazaquin is well characterized in some species [like Arbidopsis] [5] and attributed to specific base pair changes in acetohydroxy-acid synthase [AHAS] gene. Some cowpea genomic sequence is becoming available $[6,7]$ it will be of great interest to know if any mutations could be found between imazaquin tolerant and sensitive cowpea accessions.

Herbicide tolerance is the ability of the plant to grow and reproduce after herbicide application. Opinions differ on the basis of imazaquin tolerance in soybean. Tolerance of imazaquin to soybean may be due to rapid metabolism and degradation of the herbicide by the crop [8, 9]. Herbicide absorption and translocation may play minor role in imazaquin selectivity among some species [10]. Changes in coding sequence result in altering acetohydroxy-acid synthase (AHAS) enzymes which is the site of action of the herbicide may also result to imazaquin tolerance [11]. The phytotoxicity caused by imazaquin is due to inhibition of AHAS enzyme $[3,4,9,10,11,12]$. AHAS is an enzyme that is involve in synthesis of branched-chain amino acid; isoleucine, leucine and valine. Imazaquin binds to the enzyme, causing dysfunction of the enzyme and reducing the 
synthesis of isoleucine, leucine and valine that are necessary for protein synthesis. Plants resistant to acetolactate synthase (ALS) inhibiting herbicides have altered AHAS to which the herbicide does not bind [13]. Key amino acid residues within the coding site of the enzyme can protect it from imazaquin. AHAS from two lines of maize showed different spectra of herbicide tolerance compared with AHAS from sensitive maize [14]. Tolerance of cowpea to imazethapyr was due to an insensitive site of action, since extractable AHAS activity was reduced after imazethapyr application [10]. Herbicide tolerance is undesirable among weeds but desirable among crops. Herbicide tolerant crops offer a good opportunity for a farmer to control weeds. This is because of sufficient margin of selectivity between the crops and weeds such that the crop is not injured by the herbicides [15]. This gave way for new approach to herbicidal control of parasitic weed by treating the seeds of herbicide tolerant crops with a herbicide to control the obligate parasite. Use of herbicide seed treatments for parasitic weed control was first reported on cowpea in the year 1994 [16]. An ALS-inhibiting herbicidal seeds treatment was used to control Striga hermonthica in ALS-modified corn [16, 17, 18, 19]. Potentials of cinosulfuron and CGA152005 seed treatments for control of Striga hermonthica in upland rice was well documented [20]. In sorghum, seed treatments with acetolactate synthase (ALS) herbicide had successfully reduced Striga attachment to the host sorghum [15]. Herbicide seed treatments have become an important component of integrated weed management option. Identifying imazaquin tolerant cowpea can be an important land mark in the struggle to control Striga which is the most important biotic constraint to cowpea production in sub-Saharan Africa [21]. The goal was to identify imazaquin tolerant cowpea accessions and to attempt to characterize the molecular basis of such tolerance by comparing genomic sequence of annotated gene fragments of cowpea AHAS. Such information could be useful for developing imazaquin seed treatments for the control of Striga and other weeds in cowpea.

\section{Material and Methods}

\subsection{Phenotyping of Cowpea for Imazaquin Tolerance}

Table 1 provides the list of cowpea genotypes used in this study. They were obtained from US Department of Agriculture. Their seeds were imbibed with imazaquin at $0.06 \mathrm{~kg}$ active ingredient $\mathrm{ha}^{-1}$ while the control was treated with distilled water. They were planted in a mixture of soils and compost and grown in the green house of the Department of Agronomy, Purdue University West Lafayette, Indiana USA. Data were taken on number of stands per pots at 3 weeks after sowing. Mortality rate of herbicide treated genotypes were calculated as (Number of survived stand per pot at 3 weeks/ Number of planted seeds per pot) X 100 . Genotypes that recorded $70 \%(\geq 30 \%$ mortality rate $)$ and above survival rates are considered as tolerant while less than $50 \%(\geq 50 \%)$ are considered as sensitive. Young leaves from two week old plants were harvested and stored at $-80^{\circ} \mathrm{C}$ until used for DNA isolation.

Table 1. Cowpea Genotypes Used in the Molecular Study.

\begin{tabular}{|c|c|c|}
\hline Genotypes & Country of origin & 100-seeds weight(g) \\
\hline Dan arba'in & Nigeria & 118.12 \\
\hline Hen-me & Srilanka & 62.25 \\
\hline Hodi & Srilanka & 57.50 \\
\hline H.v.s 6/6 & Uganda & 71.12 \\
\hline Kibarani & Kenya & 54.12 \\
\hline Matwapa-1 & Kenya & 92.12 \\
\hline Matwapa-2 & Kenya & 55.00 \\
\hline Sokoto N & Nigeria & 108.12 \\
\hline Tvu 1392 & Kenya & 70.25 \\
\hline Tvu 1457 & Kenya & 80.37 \\
\hline Tvu 1542 & Nigeria & 74.25 \\
\hline Tvu 1638 & Kenya & 65.12 \\
\hline Tvu 1647 & Tanzania & 73.50 \\
\hline Tvu 1771 & Nigeria & 93.75 \\
\hline Tvu 1773 & Brazil, Rondonia & 82.75 \\
\hline Tvu 1801 & Kenya & 66.12 \\
\hline Tvu 1802 & Tanzania & 71.62 \\
\hline Tvu 1803 & Uganda & 77.37 \\
\hline Tvu 1908 & Nigeria & 57.37 \\
\hline Tvu 1977 & Zambia & 67.87 \\
\hline Tvu 1998 & Kenya & 54.37 \\
\hline Tvu 2003 & Tanzania & 78.62 \\
\hline Tvu 2004 & Tanzania & 71.37 \\
\hline Tvu 2018 & Tanzania & 72.00 \\
\hline UCR 236 & Tanzania & 67.12 \\
\hline UCR 237 & Tanzania & 67.00 \\
\hline UCR 242 & Tanzania & 73.25 \\
\hline UCR 243 & Tanzania & 104.00 \\
\hline V.u.6 & Kenya & 71.00 \\
\hline $\mathrm{t} 318$ & Kenya & 63.75 \\
\hline
\end{tabular}

\subsection{Genomic DNA Isolation}

Total DNA was isolated from the leaf tissues using DNA extraction kit (QIAGEN, USA) according to the manufacturer's protocol. The isolated DNA was dried at room temperature for 1 hour, dissolved in $100 \mu \mathrm{l}$ and quantified with spectrophotometer ND-100 (Themo scientific, wilmigton DE, USA) and stored at $4^{\circ} \mathrm{C}$.

\subsection{Primer Selection and Preparation}

The PCR primers used in the study were derived from cowpea Gene Space Read (GSR) sequences annotated for AHAS enzyme inhibitor from the Cowpea Genomic Knowledge Base (CGKB) website; (http://cowpeagenomics.med.virgnia.ed/CGKB). CGKB is an annotation knowledge base developed under Cowpea Genomics Initiative (CGI). The database is based on information derived from 298,848 cowpea gene space sequences (GSS) isolated by methylation filtering of genomic DNA [5]. It consists of three knowledge bases: GSS annotation and comparative genomic knowledge base, GSS enzyme and metabolic pathway knowledge base, and simple sequences repeats (SSRs) knowledge base for molecular discovery.

The primers were synthesized by IDT Integrated Technologies, USA. The name of primers and their nucleotide sequences and sizes are presented in Table 2 . The 
primers were screened for their ability to detect polymorphisms between tolerance and sensitive genotypes. Extracted DNA samples of Hen-me and Hodi were used as imazaquin tolerant while TVU 1778 and TVU 1802 were considered as sensitive genotypes.

\subsection{PCR}

Both forward and reverse primers were diluted with water base on their weight. $10 \mu \mathrm{l}$ of each primer solution was pipeted and diluted with $90 \mu \mathrm{l}$ of distilled water. $1.5 \mu \mathrm{l}$ each of forward and reverse primers was pipeted and mixed with $1.0 \mu \mathrm{l}$ of extracted DNA solution and $21 \mu$ of MangoMix (Bioline) in $0.2 \mathrm{ml} \mathrm{PCR}$ tube to make reaction volume of $25 \mu 1$.

The PCR tubes were loaded on to thermo cycler and runs for 35 circles of 30 seconds at $94^{\circ} \mathrm{C}, 35$ seconds at $55^{\circ}$ and $1.30 \mathrm{mn}$ at $72^{\circ} \mathrm{C}$ for complete 2 hours. $10 \mu \mathrm{l}$ of amplified PCR product were resolved on $5 \%$ agarose gel using $0.5 \mathrm{x}$ TBE containing Gel red with horizontal electrophoresis apparatus at $60 \mathrm{~V}$ for 2 hours. The gel was photographed using UV transillumination. The size of DNA bands in base pairs was determined using $1 \mathrm{~kb}$ ladder as standard marker. Four primers pairs were used to amplify DNA samples of sensitive and tolerant cowpea genotypes.

\subsection{Genes Sequencing}

PCR products were purified using standard procedure prescribed by QIAquick PCR purification kit according to manufacturer's recommendation. The purified DNA undergone sequencing procedures performed at Purdue Genomics core facility. Sequences were then analyzed and aligned with Codon Code Aligner using MEGA3 software.

\section{Results}

\subsection{Phenotyping 30 Diverse Cowpea Genotypes for Imazaquin Tolerance}

Based on percentage plant mortality, there were some differences in genotypic response to imazaquin tolerance at 3 weeks after sowing (Figure 1). Genotypes Hen-me and Hodi were the most tolerant with $12.5 \%$ mortality rate each. Matwapa 1 \& 2, TVU 1392, TVU 1773 and many others were among the most sensitive genotypes with $100 \%$ mortality rate. Other genotypes exhibit low to intermediate level of tolerance.

\subsection{Product Form}

Figure 2 showed the size of band produce by each primer size. Five primers $(62.5 \%)$ produce single band within the predicted size range of 400-500 bp (figure 2).

\subsection{Sequencing}

Figure 3 showed the amplified region of the cowpea AHAS annotated by CGKB. No polymorphisms were seen in this region between imazaquin tolerant and sensitive accessions.

Table 2. List of PCR Primers used Showing the Nucleotide Sequence and the Sizes.

\begin{tabular}{lll}
\hline Primer & Primer sequence & Product size (bp) Amplicon \\
\hline VuAHAS_1-F & 5'- TCG GGT AGC AGA GGA GTT TT -3' & 575 \\
VuAHAS_1-R & 5'- TTG CAG ATG CTT GTG GGA TA -3' & \\
VuAHAS_2-F & 5'- GAT TGA ATC CTG CTT CCT TCA -3' & \\
VuAHAS_2-R & 5'-GCC AAC AGA GCT CAC ACG TA -3' & \\
VuAHAS_4-F & 5'- TTC CTC AAT AAG CAA CCA TGA A -3' & \\
VuAHAS_4-R & 5'-CAG TGG GAG GAT CGG TTC TA -3' & \\
VuAHAS_5-F & 5'- TGC ATT GGT ACG AAG AAA TCT G -3' & \\
VuAHAS_5-R & 5'-GGG ATA CCA TCA GCT CGT GT -3' & \\
\hline
\end{tabular}

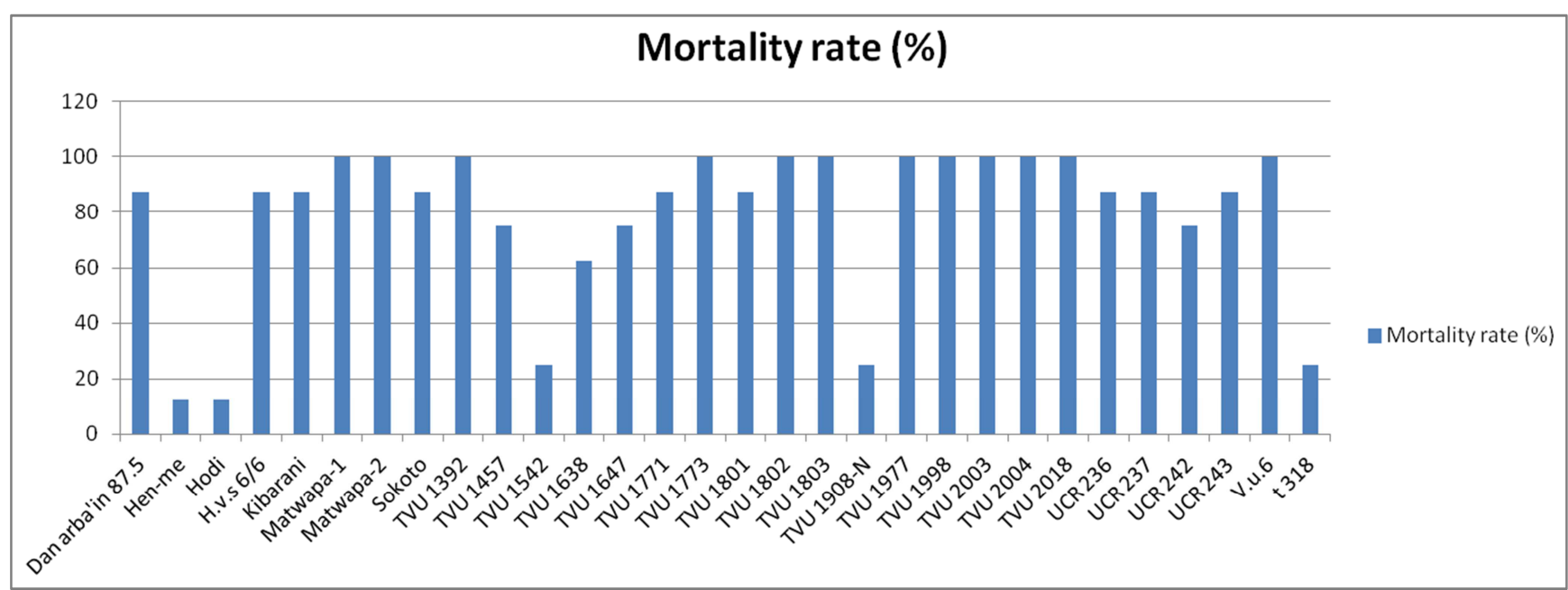

Figure 1. Mortality rate of cowpea genotypes treated with imazaquin. 


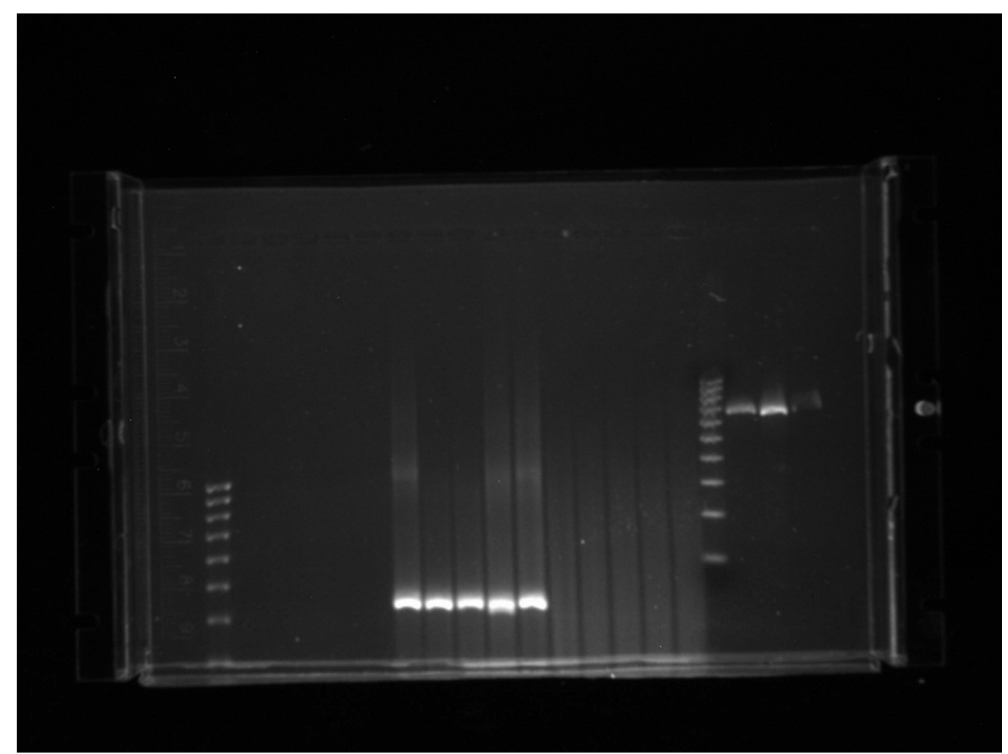

Figure 2. Agarose gel electrophoretic analysis of PCR amplified primers using the 4 primer pairs combination and DNA from imazaquin tolerant and sensitive genotypes.

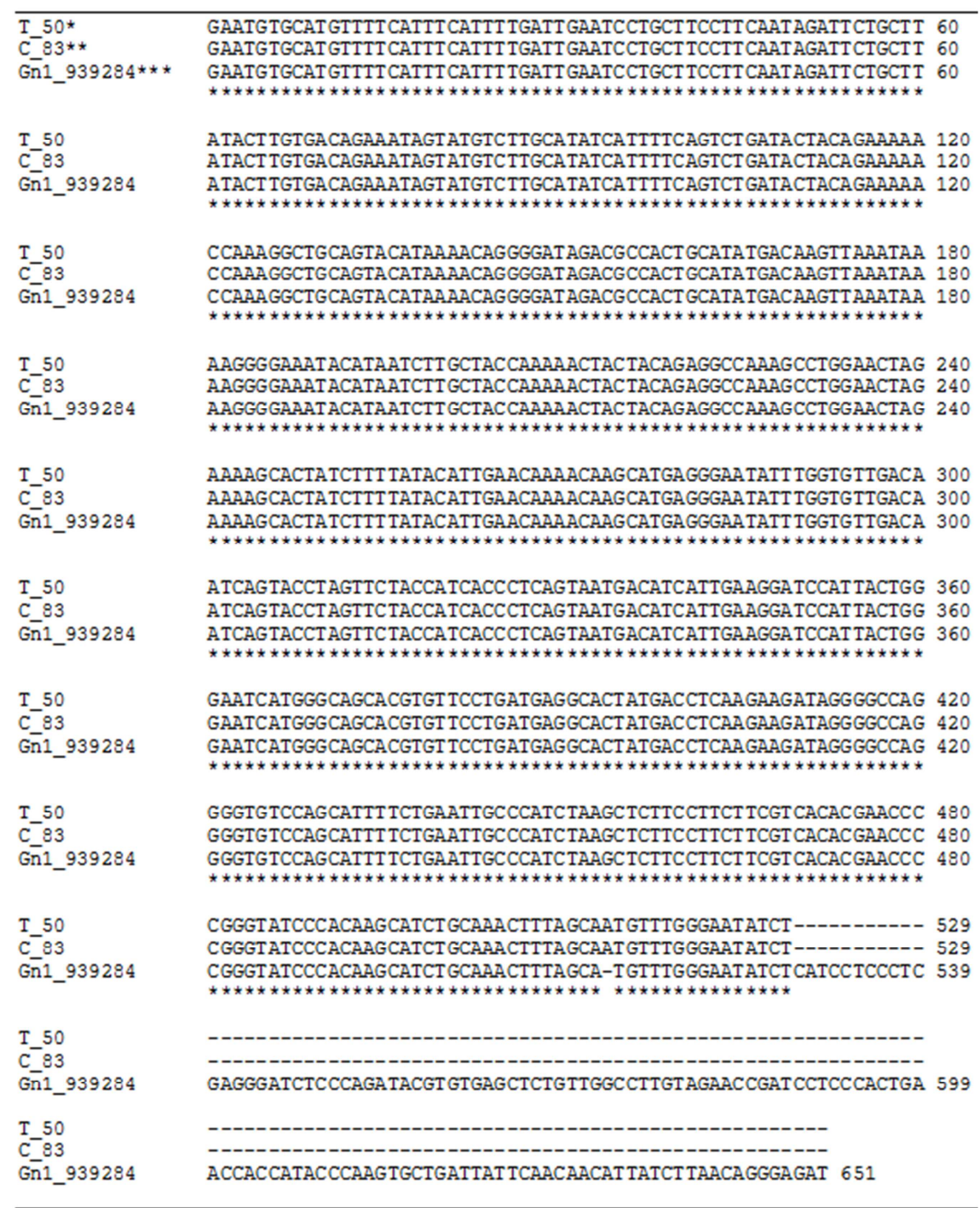

Figure 3. Sequencing of imazaquin tolerant and sensitive cowpea genotypes base on amplified region of the annotated AHAS portion from cowpea.*= Imazaquin tolerant genotype; $* *=$ Imazaquin sensitive genotype; *** = Annotated AHAS gene. 


\section{Discussion}

Absence of polymorphism between imazaquin tolerant and sensitive cowpea genotypes suggested that tolerance may not be due to inhibition of AHAS enzyme. It was earlier reported that imazaquin tolerance in soybean was due to changes in coding sequence resulting in altering AHAS (acetohydroxyacid synthase) enzymes which is the site of action of the herbicide [5]. It was also noted that differential target site sensitivity is not the bases of soybean tolerance to imazaquin since AHAS from soybean and other sensitive plant are equally sensitive to herbicide [14]. The absent of sequences in amplified region of the annotated portion of AHAS enzyme from cowpea could also be attributed to fact that the genes may belong to the same family or they are the same genes but deposited with different name. It may be possible that there may be difference elsewhere in the gene outside the amplified region. For example, from bp 518 to bp 651 were not amplified by the primers, it is possible that there could a nucleotide polymorphism within these unamplified regions of the DNA.

Tolerance of Hen-me, Hodi, TVU 1542, TVU 1908 and t318 to imazaquin (base on phenotype) could be attributed to gradual metabolism of the herbicide. It has been reported that plants differ in their ability to compensate for the damaging effects of the herbicide with no physiological mechanism involved [22]. The differences in tolerance to imazquin among plants species are caused by variations in the rate of metabolism of the parent herbicide [3]. Some soybean cultivars have displayed differential tolerance to imazaquin [23]. Selectivity of imazaquin to soybean was reported to be due to rapid metabolism and degradation of the herbicide by soybean plant [9]. Susceptible plants are either unable to metabolized the herbicide or rate of metabolism is very low. Crop tolerance to herbicides can also result from such factors as reduced absorption and translocation. Differential target site sensitivity may therefore not be the only basis for cowpea tolerant to imazaquin since there is no sequences difference in amplified region of the annotated portion of AHAS cowpea. It is possible that changes in coding sequence of AHAS enzymes play a significant role in herbicide resistance (which is inherited ability of plant to survive and reproduce following exposure to a dose of herbicide that would normally be lethal to the wild type) but not tolerance.

\section{Conclusion}

It can be concluded that the major significant difference between imazaquin tolerance and sensitive cowpea is as a result of rapid metabolic detoxification of herbicides in tolerant cowpea. It is therefore imperative that enzymology involve in the differential metabolism of this herbicide in this crop needs urgent and necessary attention.

\section{Acknowledgements}

We thank Institute for International Education USA for sponsorship to Purdue University as a Fulbright Research Scholar to conduct this research. Technical assistance by Prof. Gebisa Ejeta, Mr. Patric J. Rich and Daneil Gobena were highly appreciated.

\section{References}

[1] Ashraf M. (1985). Farming-systems Approach. In: Kim SK. (ed) Combating Striga in Africa. Proceeding of the International Workshop held in Ibadan Nigeria; on 22-24 August, 1985.pp 341-357.

[2] Davis D. W., Oeke E. A., Oplinger E. S., Doll J. D., Hanson K. V. and Putnam D. D. (1991). Field Crops Manual Alternative crop/afcm/cowpea.html.

[3] Barrett M. (1989). Reduction of imazaquin injury to corn (Zea mays) and sorghum (Sorghum bicolor) with antidotes. Weed Science, 37: 34-41.

[4] Congleton W. F., Vancantfort A. M. and Lignowski E. (1987). Imazaquin (scepter): A new soybean herbicide. Weed Technology, 1 (2): 186-188.

[5] Chen X. Laudeman T. W. Rushton P. J. Spraggins T. A. and Timko M. P. (2007). CGKB: An annotation knowledge base for cowpea (Vigna unguiculata L.) Methylation filtered genomic gene space sequences. BMC Bioinformatic, http://ww.biomedcentral.com/1471 21058/129.

[6] Li C., Fatokun C. A., Ubi B., Singh B. B. and Scoles G. J. (2001). Determining genetic similarities and relationships among cowpea breeding lines and cultivars by microsatellite markers. Crop Science, 31(1): 189-197.

[7] Timko, M. P., Pau J. R., Thomas, W. L., Marta T. B., Edmond C., Foo cheung C. D. T. and Xianfeng C. (2008). Sequencing and analysis of the gene-rich space of cowpea. BMC Genomics 9: 103-123.

[8] Riskey, M. A. and Lawrence O. L (1991). Efficacy of Imazaquin on various weed species. Weed Science 39 (2): 243250 .

[9] Tecle, B. Cunha D. A. and Shaner L. D. (1993). Differential routes of metabolism of imidazolinones: Basis for soybean (Glycine max) selectivity. Pesticide Biochemistry and Physiology 46: 120-130.

[10] Baerg R. J. and Barrett M. (1996). The basis of imazethapyr tolerance in cowpea (Vigna sinensis). Weed Science, 44: 769775 .

[11] Zhou, Q., Weiping, L., Yongsong Z. and Kevin L. (2007) Action mechanism of acetolactate synthase-inhibiting herbicides. Pesticide Biochemistry and Physiology 89: 98-96.

[12] Durner J., Gailus V. and Boger P. (1991).New aspects of inhibition of plant acetolactate synthase by chlorsulfuron and imazaquin. Plant Physiology, 95: 1144-1149. 
[13] Heap I. M. (2007). International survey of herbicide resistant weeds. Weed science society of America. http://www.weedscience.org/Accessed 11/7/2012.

[14] Stidham M. A. (1991). Herbicide that inhibits acetohydroxy acid synthase. Weed Science 39(3): 428-434.

[15] Tuinstra, M. R., Soumana S., Al-khatip K., Kapranu I., Toure A., Bastiaans A. L., Ochanda N. W., Salmi I., Kayentao M. and Dembele S. (2009). Efficacy of herbicide seed treatments for controlling Striga infestation of sorghum. Crop Science 49: 923-929.

[16] Berner D. K., Award A. E. and Aigbokhan E. I. (1994). Potentials of imazaquin seed treatments for control of Striga gesnerioides and Alectra vogelii in cowpea (Vigna unguiculata). Plant Disease, 7: 18-23.

[17] Kanampiu F. K. Ransom J. K., Gressel J., Jewell D., Freiese D., Grimanell D. and Hoisington D. (2002). Appropriateness of biotechnology to African Agriculture: Striga and maize paradigms. Plant Cell, Tissue and Organs Culture, 69: 105110.

[18] Kanampiu F. K., Ransom J. K., Friensen D. and Gressel J. (2002) b. Imazapyr and pyrithiobac movement in soil and from maize seed coats to control Striga in legume intercropping. Crop Protection, 21: 611-619.

[19] Kabambe V. H., Kananpiu F. K. and Ngwira N. (2008). Imazapyr (herbicide) seed dressing increases yield, suppresses Striga asiatica and has seed depletion role in maize (Zea mays L.) in Malawi. African Journal of Biotechnology, 7(18): 32933298.

[20] Adagba M. A., Lagoke S. T. O. and Singh B. N. (2002). Potentials of Cinosulfuron and CGA152005 seed treatment for control of Striga hermonthica in upland rice. Act Agronomica Hungarica, 50(1): 7-18.

[21] FAO. (2005). Status research and application of crop biotechnology in developing countries. http:www.Fao.org/docrep/008/y5800e/y 5800.htm. Accessed 9/15/2012.

[22] Menalled F, D. and Dyer W. E. (2006). Preventing and managing herbicideresistance in Montana. MSU Extension Montana Guige. MT 200506AG.

[23] Newsom L. J. and Shaw D. R. (1992). Soybean (Glycine max) cultivar tolerance to chlorimuron and imazaquin with varying hydoponic solution $\mathrm{pH}$. Weed Technology, 6(2): 382-388. 